\title{
学会活動の新展開
}

\section{多田 邦雄*}

今年は本会が設立されて 10 周年目という記念すべき年であり，また 1 年前か らの学会名称変更に伴う諸改革も順調に推移していることも含め, ご一緒に慶 賀したい。

本会の個人会員数は昨年11月現在で1278名である。回路実装産業の重要性や 広域性から考えると，この会員数は比較的少ないようにみえる。会員数がそれ ほど多くはないということは, 学会のせっかくの有益な活動が十分利用されて いないという点で残念であるだけでなく, 学会活動のより一層の活性化へのブ レーキにもなりかねない問題である。学会理事会では真剣な論議が行われ，学 会誌に昨年11月号から “会員増強ご協力の㹉い”が明瞭な形で揭載されるよ うになったのは，大きな前進である。

一般に学会というものが会員数を維持し増強するための基礎として, 会費に 見合う十分なサービスが提供されること, 新分野や関連分野も積極的に取り込 むことなどが重要と思われる。

回路実装学会は, 学会誌を刊行し, 学術講演大会を定期開催し, 教育講座, セミナー, ワークショップ, 研究討論会, 公開研究会, 特別企画講演会などの 催物も随時活発に開催している。これら技術的活動やサービス提供の母体とし て, 一昨年以来11の技術委員会が整備され, その活動成果は例えば本号の特集 内容などにも反映されている。以上を総合してみると，本会はサービスが充実 しており，むしろ会員数規模からみると大いに健闘しているといえよう。こう いった点が産業界や学界に十分認識されて, 会員増強に結び付くことを, まず 第一に望みたい。

回路実装の重要性はよくわかるが実際的でやや地味な分野である, という印 象が世間にあることは事実であろう。大学関係者や学生, 若手技術者などの参 加を促すには，新分野，先端的研究開発項目を積極的にとり上げる必要がある。 その意味で光回路実装技術委員会が設置されたことの意義は大きく，この委員 会自体や，その編集による学会誌昨年 8 月臨時増刊 “光回路実装技術” 特集号 などは，我が国で初めての試みと思われ，今後の展開が期待される。他にも， マイクロ波・ミリ波回路の新しい実装技術など，とり上げたいおもしろい新課 題がいろいろあるのではなかろうか。

標準化活動を学会に関連付けることもできよう。IEC（国際電気標準会議） のTC52（プリント回路部会）は日本プリント回路工業会が担当しているが, その所産についての教育普及活動は学会側で分担するのもよいのではなかろう か。IECでは他にTC91(表面実装技術部会)があり，TC52,TC40（電子機器用コ ンデンサ・抵抗器部会), TC47 (半導体デバイス部会), TC50 (環境試験部会), TC93（デザインオートメーション部会）等と協力しながら，国際規格作成活 動を展開中である。このような標準化活動の例に限らず，回路実装には関連分 野が多く関係者も大勢打られるので, これら関連分野の方々に学会に加入して いただく方策も考えるべきであろう。 